\title{
Preservation Technique of Dwarf Elephant Grass Cuttings (Pennisetum purpureum CV mott.)
}

\section{Desy Valentina P, Nevy Diana Hanafi, Tri Hesti Wahyuni, and Achmad Sadeli}

Animal Husbandry Program Study, Faculty of Agriculture, Universitas Sumatera Utara, Indonesia

\begin{abstract}
The breeding of dwarf elephant grass generally uses vegetative methods, namely using cuttings. The constraints faced and the distribution of cuttings are the nature of which are easily damaged during storage due to physiological activities and invasion of microorganisms. This study aims to find a number of preservation techniques that can maintain the age and quality of dwarf elephant grass cuttings (Pennisetum purpureum cv mott.). This research was carried out in the Faculty of Agriculture Universitas Sumatera Utara, starts from July to August 2018. The design used is a 5 x 5 factorial complete randomized design (RAL), with 4 replications each consisting of 3 cuttings. The results showed that the general condition of the cuttings planting material was better until storage for 20 days, namely A4; the average shrinkage weight of the cuttings is significantly different in the A4 (refrigerator) treatment that is equal to 1.532 and the longer it is stored the higher the weight loss; the average power grows is significantly different in treatment A1 (wax) which is equal to 1.950 and the longer it is stored the lower the power to grow cuttings. The average vertical height is significantly different from the A1 treatment (wax) with a value of 10,585 .
\end{abstract}

Keywords: cuttings, dwarf elephant grass, preservation

Received 24 February 2018 | Revised 19 March 2018 | Accepted 23 March 2018

\section{Introduction}

Dwarf elephant grass (Pennisetum purpureum cv mott) is a superior type of grass that has high productivity and nutrient content and has high palatability for ruminants. This plant is one type of animal feed quality and is preferred by cattle [1].

Constraints faced and the distribution of cuttings planting material are properties that are easily damaged during storage due to physiological activities and invasion of microorganisms. This will lead to decrease organic matter content in cuttings, especially carbohydrate content. Storage is an effort to protect food from damage caused by pests such as microorganisms, insects, and physiological damage [2].

\footnotetext{
*Corresponding author at: Animal Husbandry Study Program, Faculty of Agriculture, Universitas Sumatera Utara, Jl. Prof. Sofyan No. 3, Medan 20155, Indonesia

E-mail address: nevydiana@yahoo.co.id
} 
One of the factor that influence the success of cuttings is the balance of carbohydrates $(\mathrm{KH})$ and nitrogen-containing compounds when planting cuttings requires protection from direct sunlight [3].

Preservation techniques are carried out by wax coating, adding silica gel, immersion with sugar water and storage in a refrigerator.

It is assumed that the treatment with wax coating preservation, addition of silica gel, sugar water dyeing and refrigerator storage on dwarf elephant grass cuttings are able to maintain the quality of dwarf elephant grass cuttings.

\section{Materials and Research Methods}

\subsection{Place and Time Research}

This research was carried out in the Experimental Field of the Faculty of Agriculture, Universitas Sumatera Utara Jl. A. Sofyan No. 3 Medan, located at an altitude of $25 \mathrm{~m}$ above sea level for 2 months from May to June 2018.

\subsection{Materials and Research Tools}

Materials used in this study were dwarf elephant grass (Pennisetum purpureum cv mott) aged 25 months, with a length of cuttings between $5 \mathrm{~cm}$ or two to three books of one segment. Cuttings were obtained from the Research Workshop (Lolit) Kambing Sei Putih Galang, Deli Serdang District, North Sumatra, as many as 300 cuttings. The preservatives used in this study were $2 \%$ sugar solution, paraffin wax, natural type silica gel, and ultisol soil. The tools used are refrigerators, sacks, ropes, polybags, hoes, machetes, analytical scales, and books

\subsection{Research Methods}

This research was carried out in 2 phases, namely: (1) Preservation and Storage, (2) Planting and Maintenance

\subsubsection{Stage 1. Preservation and storage}

At this stage preservation and storage are carried out with several treatments, namely: (1) Refrigeration Machine (Refrigerator), (2) Sugar, (3) Candles, (4) Silica gel.

\section{a. Implementation of wax dyeing}

Research Paraffin wax material is liquefied with a temperature of $66-68{ }^{\circ} \mathrm{C}$ and is waited until the temperature decreases $\left(40-45^{\circ} \mathrm{C}\right)$. The cuttings that have been weighed are then dipped 1.5 $\mathrm{cm}$ long on both ends of the cuttings. The cuttings that have been treated are then allowed to stand until the wax layer solidifies and then put into a sack and tightly bound and stored in a place that is not exposed to direct sunlight. 


\section{b. Sugar Liquid Dyeing}

Sugar solution is made at a concentration of $2 \%(20 \mathrm{~g} / \mathrm{liter}$ of water). The cuttings that have been weighed are then dipped along 1.5 at both ends. The cuttings that have been treated are then allowed to stand until there is no liquid sugar dripping and then put into sacks and tightly tied and stored in a place that is not exposed to direct sunlight.

\section{c. Addition of silica gel}

Cuttings that are ready to be preserved are weighed and then put into sacks together with silica gel which has been packaged for $\pm 15 \mathrm{~g}$. Silica gel is divided into 3 packages, each containing 5 $\mathrm{g}$ and placed at the bottom, middle, and top of the cuttings and then sacks tightly bound and stored in a place that is not exposed to direct sunlight.

\section{d. Use of refrigeration machines (refrigerator)}

Use of Cooling Machines (Refrigerators) Cuttings that have been weighed are put into sacks and arranged upright (standing) then the sack is tightly bound and put into a refrigerator at $4-5^{\circ} \mathrm{C}$.

\section{e. Observed variables}

- General conditions of cuttings

General conditions were observed from changes in color, smell and texture of the cuttings after each storage treatment was given.

- Depreciation of the weight of the cutting

The weight of the cuttings is weighed before being treated with storage and after storage then the difference in the weight of the cuttings is calculated.

(Difference in cuttings weight $(\mathrm{g})$ = initial cuttings weight $(\mathrm{g})$ - final cuttings weight $(\mathrm{g})$ ).

\subsubsection{Stage 2. Planting and maintenance}

After the preservation and storage in stage 1, cuttings are planted and maintained.

\section{a. Planting}

Cuttings planted in polybags using ultisoil soil type with a sleeping position $\left(180^{\circ}\right)$ and one polybag consisting of one cuttings.

\section{b. Maintenance plant}

Maintenance includes several activities including watering and weeding. 1) Watering plants is carried out twice a day, namely in the morning and evening, especially if the rain does not come down so that water is available longer in the soil and avoid dead / wilt cuttings. 2) Weeding is done manually by removing weeds around the plant. 


\section{c. Observed variables}

- Growth power

General conditions are seen in the number of cuttings that grow after planting. Growth is seen after two leaves appear. Then observed the length of plant growth (the appearance of two leaves) in each treatment.

- Vertical height

Vertical height of cuttings was measured after 2 weeks of observation (14 days after planting).

\subsection{Data Analysis}

The study was carried out using a 5 x 5 factorial complete randomized design (CRD) method, with 4 replications and each replication consisting of 3 cuttings. Factor A is the treatment of the tool / preservative and factor B in the storage period. Analysis model used

$$
\text { Yijk }=\mu+a i+b j(a b) i j+e i j k
$$

Description:

Yijk $=$ observation value for preservative treatment $(B 1, \ldots, B 5) \mathrm{j}$ and repeat

$\mathrm{k} \mu=$ general average

ai $=$ effect of treatment $\mathrm{A}$ to $\mathrm{i}$

$\mathrm{bj} \quad=$ effect of treatment $\mathrm{B}$ to $\mathrm{j}(\mathrm{ab})$

$\mathrm{ij}=$ the effect of the $\mathrm{i}$ preservative ingredient interaction and storage duration $\mathrm{j}$

eijk $=$ factor $\mathrm{A}$ to $\mathrm{i}$ error, $\mathrm{j}$ factor $\mathrm{B}$ and ke-k replication

\section{Result and Discussion}

\subsection{General Conditions of Planting Material Cuttings}

Observation of the general condition of cuttings aims to determine the physical properties, quality and growth power of cuttings during storage. Common conditions of cuttings observed include color, odor, and texture of cuttings (wrinkles). Observation of color, odor, and physical changes can be seen in Table 1. The longer the cuttings are stored, the more obvious the changes that occur in the cuttings. 
Table 1. Changes in Color, Smell, Physical (Fungus), and Texture of the Cuttings Stored by Using Sugar, Wax, Silica Gel and Refrigerator with Different Storage Times.

\begin{tabular}{|c|c|c|c|c|c|}
\hline \multirow{2}{*}{ Treatment } & \multicolumn{5}{|c|}{ Storage Time } \\
\hline & 4 & 8 & 12 & 16 & 20 \\
\hline \multicolumn{6}{|l|}{ Control } \\
\hline Color & - & + & ++ & ++ & +++ \\
\hline Smell & - & + & ++ & +++ & +++ \\
\hline Physical (Fungus) & + & + & ++ & ++ & +++ \\
\hline Texture & - & + & ++ & +++ & +++ \\
\hline \multicolumn{6}{|l|}{ Wax } \\
\hline Color & - & - & + & ++ & +++ \\
\hline Smell & - & + & + & ++ & +++ \\
\hline Physical (Fungus) & - & - & + & + & +++ \\
\hline Texture & - & ++ & ++ & +++ & +++ \\
\hline \multicolumn{6}{|l|}{ Silica Gel } \\
\hline Color & - & + & + & ++ & +++ \\
\hline Smell & - & +++ & +++ & ++++ & +++ \\
\hline Physical (Fungus) & - & + & + & ++ & +++ \\
\hline Texture & - & + & ++ & +++ & ++++ \\
\hline \multicolumn{6}{|l|}{ Sugar } \\
\hline Color & - & - & + & ++ & +++ \\
\hline Smell & - & - & +++ & +++ & ++++ \\
\hline Physical (Fungus) & - & + & ++ & +++ & ++++ \\
\hline Texture & - & + & + & ++ & +++ \\
\hline \multicolumn{6}{|l|}{ Refrigerator } \\
\hline Color & - & - & - & - & - \\
\hline Smell & - & - & - & - & - \\
\hline Physical (Fungus) & - & - & - & - & - \\
\hline Texture & - & - & - & - & - \\
\hline
\end{tabular}

Information: Sign (-) : ther have been no changes, $(+)$ : changes have occured and the more $(+)$, the change willl increase there has been no change.

Based Tabe 1, it can be seen that the treatment with refrigerator storage techniques is better than other treatments because there is no change until the 20 day.

\subsection{Depreciation of Cuttings Weight, Power Grows and Vertical Height}

The results of further test analysis showed that the treatment of preservation techniques and storage time had a significant effect $(\mathrm{P}<0.05)$ on the shrinkage of the weight of dwarf elephant grass cuttings (Pennisetum purpureum cv mott). The lowest average weight loss is in the refrigerator storage technique compared to other storage techniques, namely $1.532 \mathrm{~g}$. The highest average cuttings weight during storage is cuttings with a control treatment that is equal to 7.277 g. Depreciation parameters significantly different in the refrigerator (A4).

The growth power of cuttings was observed to determine whether there was any effect of preservation treatment and storage duration on cuttings growth. From these observations can be 
known preservation treatment and effective storage time for storing cuttings so that it will facilitate the distribution of dwarf elephant grass cuttings.

Table 2. The Average Shrinkage of Cuttings Weight (g), Growht Power, and Vertical Hight

\begin{tabular}{|c|c|c|c|c|c|c|}
\hline \multirow{2}{*}{$\begin{array}{c}\text { Preservation } \\
\text { Technique }\end{array}$} & \multicolumn{5}{|c|}{ Storage Time } & \multirow{2}{*}{ Average } \\
\hline & B1 & B2 & B3 & B4 & B5 & \\
\hline A0 & 2.036 & 4.518 & 8.915 & 8.537 & 12.381 & $7.277^{\mathrm{a}}$ \\
\hline A1 & 1.561 & 3.254 & 4.162 & 6.650 & 7.263 & $4.578^{b}$ \\
\hline A2 & 1.736 & 5.867 & 7.056 & 9.239 & 10.987 & $6.977^{\mathrm{a}}$ \\
\hline A3 & 1.517 & 6.402 & 6.693 & 9.353 & 11.89 & $7.171^{\mathrm{a}}$ \\
\hline A4 & 0.245 & 0.321 & 0.84 & 1.89 & 4.365 & $1.532^{\mathrm{c}}$ \\
\hline Average & $1.419^{\mathrm{e}}$ & $4.072^{\mathrm{d}}$ & $5.533^{\mathrm{c}}$ & $7.134^{\mathrm{b}}$ & $9.377^{\mathrm{a}}$ & \\
\hline A 0 & 1.500 & 1.250 & 1.000 & 0.750 & 0.500 & $1.000^{\mathrm{ad}}$ \\
\hline A1 & 3.000 & 2.250 & 1.750 & 1.500 & 1.250 & $1.950^{\mathrm{a}}$ \\
\hline A2 & 2.500 & 1.500 & 1.250 & 1.000 & 0.750 & $1.400^{\mathrm{b}}$ \\
\hline A3 & 2.000 & 1.500 & 1.250 & 1.000 & 0.750 & $1.300^{\mathrm{bc}}$ \\
\hline A4 & 0.000 & 0.000 & 0.000 & 0.000 & 0.000 & $0.000^{\mathrm{de}}$ \\
\hline Average & $1.800^{\mathrm{a}}$ & $1.300^{\mathrm{b}}$ & $1.050^{\mathrm{bc}}$ & $0.850^{\text {bcd }}$ & $0.650^{\text {cde }}$ & \\
\hline A0 & 6.832 & 6.125 & 4.388 & 3.677 & 2.057 & $4.616^{\mathrm{cd}}$ \\
\hline A1 & 15.583 & 13.875 & 10.427 & 7.207 & 5.832 & $10.585^{\mathrm{a}}$ \\
\hline A2 & 14.654 & 10.250 & 7.230 & 6.207 & 4.125 & $8.493^{\mathrm{ab}}$ \\
\hline A3 & 14.000 & 7.520 & 5.500 & 4.083 & 2.580 & $6.737^{\mathrm{bc}}$ \\
\hline A4 & 0.000 & 0.000 & 0.000 & 0.000 & 0.000 & $0.000^{\mathrm{e}}$ \\
\hline
\end{tabular}

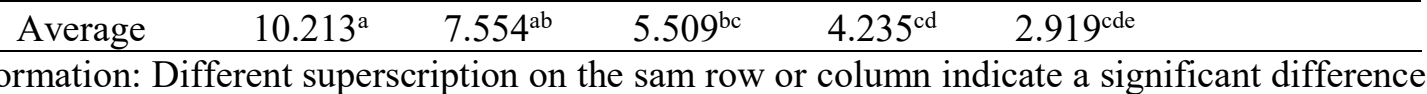
in the Duncan test $(\mathrm{p}<0,05)$

The results of the analysis of variance showed that the treatment of preservation techniques and storage time had a significant effect $(\mathrm{P}<0.05)$ on the power to grow dwarf elephant grass cuttings (Pennisetum purpureum $c v$ mott). Based on Table. 2, it can be seen that the highest value of growing power is in the treatment of preservation with wax (A1) because the coating of cuttings with wax can minimize the occurrence of respiration (water evaporation) so that the cuttings still have food reserves to grow and prevent cuttings to lose carbohydrates and nitrogen. In all treatments the longer the cuttings are stored, the fewer cuttings grow. The cuttings growth parameters were significantly different on wax coating treatment (A1). The lowest average power growth value is found in the refrigerator preservation technique (A4) with a value of 0 because there is no cuttings that grow this is caused by temperature changes that occur when the cuttings are moved from the refrigerator to the polybag. Wax is found both in plants and animals. Wax in plants are found on the surface of leaves and stems which function to protect the plants from evaporation or insect attack [4].

Based on Table 2 it can be seen that the highest vertical height is found in the preservation treatment with wax coating that is $10.585 \mathrm{~cm}$ because the coating of cuttings with wax can reduce the occurrence of the respiration process so that the cuttings still have food reserves while the lowest vertical height is found in the refrigerator treatment which is $0.000 \mathrm{~cm}$ because no cuttings grow in this treatment. Table 2 shows the vertical height average on the cuttings that 
the interaction between pickling treatment and storage time did not have a significant effect $(\mathrm{P}>$ 0.05). However, the duration of storage and use of preservatives had a significant effect ( $P$ $<0.05$ ) on increasing vertical height. Data in Table 2 is known in all preservation treatments with a storage time of 4 days $(\mathrm{P}<0.05)$ indicating a vertical height average that is better than other storage times. Then the higher the storage time, the vertical height will decrease.

\section{Conclusion}

For appication to the field preservation treatment with wax is better than other treatments because it has average power value grows and the high of vertical height.

\section{REFERENCES}

[1] N.A. Syarifuddin, Nilai Gizi Rumput Gajah Sebelum dan setelah Enzilase pada Berbagai Umur Pemotongan. Skripsi, Fakultas Pertanian Universitas Lampung, 2006.

[2] E. Damayanthy and Mudjajanto, Teknologi Makanan. Jakarta, Departemen Pendidikan dan Kebudayaan Direktorat Jenderal Pendidikan Dasar dan Menengah Direktorat Pendidikan Menengah Kejuruan Proyek Peningkatan Pendidikan dan Kejuruan Non Teknik II, 1995.

[3] K. Rochman and S. S. Haryadi, Pembiakan Vegetatif. Bogor: Departemen Agronomi Institut Pertanian Bogor, 1973.

[4] Agribisnis Deptan, Pengawetan Bunga Potong. Jakarta: Departemen Pertanian, 2008. 